\title{
Erratum to: A global approach for sparse representation of uncertainty in Life Cycle Assessments of waste management systems
}

\author{
Valentina Bisinella $^{1}$ - Knut Conradsen ${ }^{2}$ - Thomas Højlund Christensen ${ }^{1}$. \\ Thomas Fruergaard Astrup ${ }^{1}$
}

Published online: 15 February 2017

(C) Springer-Verlag Berlin Heidelberg 2017

Erratum to: Int J Life Cycle Assess

DOI 10.1007/s11367-015-1014-4

In the original version of this article, unfortunately the link to the Electronic Supplementary Material was missing. This link is now provided here.

The online version of the original article can be found at http://dx.doi.org/ 10.1007/s11367-015-1014-4.

Electronic supplementary material The online version of this article (doi:10.1007/s11367-016-1259-6) contains supplementary material, which is available to authorized users.

Valentina Bisinella

valenb@env.dtu.dk

1 Department of Environmental Engineering, Technical University of Denmark, Miljoevej, Building113, 2800 Kongens Lyngby, Denmark

2 Department of Applied Mathematics and Computer Science, Technical University of Denmark, Richard Petersens Plads, Building 321, 2800 Kongens Lyngby, Denmark 